\title{
Psettarium anthicum sp. n. (Digenea: Sanguinicolidae) from the heart of cobia Rachycentron canadum (Rachycentridae) in the northern Gulf of Mexico
}

\author{
Stephen A. Bullard and Robin M. Overstreet
}

Gulf Coast Research Laboratory, Department of Coastal Sciences, The University of Southern Mississippi, P.O. Box 7000, Ocean Springs, Mississippi 39566-7000, USA

Key words: Digenea, Sanguinicolidae, Psettarium anthicum, blood fluke, Rachycentron canadum, cobia, heart, Gulf of Mexico

\begin{abstract}
Psettarium anthicum sp. n. (Digenea: Sanguinicolidae) infects the myocardium and atrial wall of the cobia Rachycentron canadum (Linnaeus, 1766) (Rachycentridae) in the northern Gulf of Mexico off Mississippi, USA. It is the first member of Psettarium Goto et Ozaki, 1930 reported from other than the Indian Ocean or Pacific Ocean and the second species of the genus reported from cobia. It differs from its congeners by the combination of having posterior caeca with lateral projections appearing as thorns in lateral view and the male pore anterior to the oötype. The species of Psettarium, P. japonicum (Goto et Ozaki, 1929) (type species), P. tropicum Manter, 1940, P. sebastodorum Holmes, 1971, P. rachycentri (Lebedev et Parukhin, 1972) comb. n. (syn. Psettarioides rachycentri Lebedev et Parukhin, 1972) and P. anthicum sp. n., differ from other sanguinicolids by the combination of having an elongate body with a sinistral posterolateral protuberance, minute, straight tegumental body spines in ventrolateral transverse rows, posterior caeca greater than seven time the anterior caeca length, the oötype near the posterior end of the body, a uterus primarily between the ovary and oötype and an oviduct and vitelline duct extending posteriad primarily between the uterus and dextral body margin. We emend Psettarium and provide a diagnostic key to the species. Psettarioides is regarded as a junior synonym of Psettarium because herein we return its type species, $P$. tropicum, to Psettarium. Regarding the three other sanguinicolids formerly of Psettarioides, we suspect that $P$. pseudupenei Lebedev et Parukhin, 1972 belongs to Psettarium but include it only tentatively pending an examination of type or other material; we tentatively place $P$. kurochkini Parukhin, 1976 in Cardicola Short, 1952; and we designate P. grandis (Lebedev et Mamaev, 1968) as incertae sedis pending examination of type or other appropriate material.
\end{abstract}

The nominal species of Psettarium Goto et Ozaki, 1930 (Digenea: Sanguinicolidae) infect the mesenteric vessels of two puffers (Tetraodontidae) in the Pacific Ocean (Goto and Ozaki 1929, Manter 1940), the heart and ventral aorta of rockfishes (Sebastidae) in the Eastern Pacific Ocean (Holmes 1971a) and the kidney of the cobia Rachycentron canadum (Linnaeus, 1766) (Rachycentridae) in the Indian Ocean (Lebedev and Parukhin 1972). We describe a new species of Psettarium from the heart of cobia in the Gulf of Mexico, bringing the total number of blood flukes known from fishes in that region to nine (Linton 1910, Manter 1947, Short 1952, 1953, 1954, Smith 1997, Bullard and Overstreet 2003, 2004, Bullard et al. in press) and the total number of species within Psettarium to five. This report of a hitherto unnamed sanguinicolid from cobia in the Gulf of Mexico is significant because the cobia is a candidate for offshore cage culture in the Gulf of Mexico and, given appropriate environmental conditions, blood flukes can be serious pathogens of cage-cultured fishes (Bullard and Overstreet 2002).

\section{MATERIALS AND METHODS}

Cobia were captured by hook and line from Ship Island, Mississippi, USA, and from beneath or near oil platforms, channel markers, sargassum mats and floating debris in the Northern Gulf of Mexico during the summers of 1999 through 2003. Cobia were pithed immediately after capture, and the heart was extracted, placed in a sample bag, bisected, sprayed with 8.5 ppt sodium chloride $(\mathrm{NaCl})$ solution or an anticoagulant solution of $5.0 \mathrm{gm} \mathrm{NaCl}$ and $2.0 \mathrm{gm} \mathrm{Na-citrate} \mathrm{di-}$ hydrate/L of distilled water and temporarily stored on ice. Upon returning to the laboratory, usually several hours after the cobia were killed, the bisected heart and the contents of the bag were examined under a dissecting microscope. Live flukes were extracted from cardiac muscle using artist's brushes, fine forceps and a scalpel, killed under slight coverslip pressure with heat from an ethanol-burner flame and transferred to a vial of $5-10 \%$ neutral phosphate buffered formalin. Whole mounts were stained in Van Cleave's and Ehrlich's haematoxylin, alkalinized at $70 \%$ ethanol with lithium carbonate and butylamine, dehydrated, cleared in clove oil and mounted in Canada balsam. Specimens for scanning electron microscopy 
(SEM) were dehydrated, immersed in hexamethyldisilazane for $15 \mathrm{~min}$, air-dried for $45 \mathrm{~min}$, and sputter-coated with goldpalladium. Mounted specimens were illustrated using a drawing tube. Measurements are reported in $\mu \mathrm{m}$ and given as the range followed by the sample size in parentheses.

\section{RESULTS}

\section{Psettarium Goto et Ozaki, 1930}

Synonymy: Plehnia Goto et Ozaki, 1929; preoccupied Psettarium Goto et Ozaki, 1930

Psettarioides Lebedev et Parukhin, 1972

Diagnosis. Body of adult thin, flat, ventrally concave, elongate, having sinistral posterolateral protuberance, spined; tegumental body spines in ventrolateral transverse rows, minute, straight. Fused or rosethornshaped spines lacking. Oral sucker and pharynx lacking. Mouth medioventral, subterminal. Oesophagus $\leq 25 \%$ of body length, extending directly posteriad along midline. Alimentary tract H-shaped, having paired anterior and posterior caeca; anterior caeca short, approximately equal in length, lacking lateral projections; posterior caeca $\geq 7 \times$ length of anterior caeca, having or lacking lateral projections appearing as thorns in lateral view. Testis medial; post-testicular space $\leq 25 \%$ of body length. Auxiliary external seminal vesicle lacking. Cirrus-sac post-gonadal, sinistral. Ovary post-caecal, posttesticular, lobed. Laurer's canal lacking. Common vitelline duct and oviduct extending posteriad primarily between uterus and dextral body margin. Oötype medial, near posterior end of body; post-oötype space $<10 \%$ of body length. Uterus occupying space primarily between ovary and oötype. Metraterm indistinct. Female pore sinistral, dorsal, anterior to male pore. Infecting vascular system of marine teleosts.

Differential diagnosis. Body elongate, having sinistral posterolateral protuberance. Tegumental body spines in ventrolateral transverse rows, minute, straight. Posterior caeca $\geq 7 \times$ length of anterior caeca. Oötype near posterior end of body. Uterus primarily between ovary and oötype. Oviduct and vitelline duct extending posteriad primarily between uterus and dextral body margin.

Type species:

Psettarium japonicum (Goto et Ozaki, 1929)

Synonymy: Plehnia japonica Goto et Ozaki, 1929

Other species:

Psettarium japonicum Goto et Ozaki, 1930

Psettarium tropicum Manter, 1940.

Synonymy: Cardicola tropicus Lebedev et Mamaev, 1968

Psettarioides tropicum Lebedev et Parukhin, 1972

Psettarium rachycentri (Lebedev et Parukhin, 1972) comb. n.

Synonymy: Psettarioides rachycentri Lebedev et Parukhin, 1972
Remarks. Lebedev and Parukhin (1972) erected Psettarioides Lebedev et Parukhin, 1972 and included P. tropicum Manter, 1940 (type species), P. rachycentri Lebedev et Parukhin, 1972, P. grandis (Lebedev et Mamaev, 1968) (originally as Cardicola grandis), and $P$. pseudupenei Lebedev et Parukhin, 1972, with the later addition of P. kurochkini Parukhin, 1976. Lebedev and Mamaev (1968) previously had transferred $P$. tropicum to Cardicola Short, 1952 without discussion. Lebedev and Parukhin (1972) did not provide a tenable diagnosis of Psettarioides or differentiate any species from Psettarium japonicum. Based on the presence of an elongate body that has a sinistral posterolateral protuberance, posterior caeca that are $\geq 7 \times$ the length of the anterior caeca, an oötype that is located near the posterior end of the body, a uterus that is primarily between the ovary and the oötype, and an oviduct and vitelline duct that each extend posteriad primarily between the uterus and the dextral body margin, we consider Psettarioides tropicum (the type species) and $P$. rachycentri congeneric with $P$. japonicum. Consequently, we consider Psettarioides a subjective junior synonym of Psettarium.

Although we consider $P$. tropicum and $P$. rachycentri to clearly belong to Psettarium, the identities of the three remaining species formerly of Psettarioides, $P$. pseudupenei, P. kurochkini, and P. grandis, are problematic because the original descriptions lack the detail needed to confidently place them in genera. Because of this and our lack of access to type or appropriate material, we are relegated to speculating on their systematic position. Based solely on fig. 2 of Lebedev and Parukhin (1972), P. pseudupenei would not fit in Psettarium because the figure suggests the species lacks a posterolateral protuberance and has a long oesophagus, $>1 / 3$ body length, and short posterior caeca that are $<2 \times$ anterior caeca length. Nevertheless, we tentatively place the species in Psettarium until an assessment of type or other appropriate material demonstrates that it belongs to Psettarium or a new, closely-related genus with members having a lobed ovary, a uterus between the ovary and oötype and an oviduct and vitelline duct extending posteriad between the uterus and the dextral body margin. We tentatively assign $P$. kurochkini to Cardicola Short, 1952 as C. kurochkini (Short, 1952) n. comb. because it apparently lacks a posterolateral protuberance and it has an ovoid body, an inter-caecal testis that fills the space between the ovary and caecal intersection and a uterus that extends posterior to the oötype; all of which are typical features of Cardicola spp. (see Parukhin 1976, Bullard and Overstreet 2004). Regarding $P$. grandis, the highly stylized fig. $\mathrm{b}$ of Lebedev and Mamaev (1968) lacks a posterolateral protuberance and shows a spheroid, inter-caecal testis and a bulbous oviducal seminal receptacle, none of which we consider generic features of Psettarium. Based on this illustration and the unlikeliness that the species belongs in Psettarium, we regard $P$. grandis as incertae sedis pending critical assessment of type or other appropriate material. 
The most recent diagnosis of Psettarium is by Smith (2002), who accepted Psettarioides. The diagnosis of Psettarium herein differs from that of Smith (2002) by including detail about the relative position of the vitelline duct, oviduct, and proximal portion of the uterus, which we think reliably distinguishes species of Psettarium from many other sanguinicolids. The status of Psettarioides is discussed below.

Some features reported for the species formerly of Psettarioides are dubious and need confirmation. We have not observed a clearly-delineated "buccal capsule" (see Smith 2002) or "mouth capsule" (see Lebedev and Parukhin 1972) in any sanguinicolid, and these structures are not described in detail by any author. We suspect that the so-called capsule might comprise the anterior portion of an oesophageal gland surrounding the refractive wall of the oesophagus, a common feature among sanguinicolids. The presence of a uterine seminal receptacle also needs confirmation in at least $P$. grandis and $P$. pseudupenei. In the text description of $P$. grandis (see Lebedev and Mamaev 1968), a uterine seminal receptacle is described; however, only an oviducal seminal receptacle is illustrated. Similarly, only an oviducal seminal receptacle is illustrated for $P$. pseudupenei. Further, some species formerly of Psettarioides lacked the features included in the diagnosis of Smith (2002). For example, P. tropicum, P. pseudupenei and $P$. kurochkini apparently have smooth posterior caeca rather than "caecal branches" (= the lateral projections appearing as thorns in lateral view?); P. grandis has a spherical testis located immediately posterior to the caecal intersection rather than one that reaches the ovary; $P$. kurochkini and $P$. grandis each have an ovoid ovary with smooth margins rather than one that is fanshaped or lobed; and the uterus of $P$. kurochkini and $P$. grandis is illustrated as being highly convoluted but not coiled by Parukhin (1976) and Lebedev and Mamaev (1968)

\section{Psettarium anthicum sp. n.}

Figs. 1-8

Description (based on 5 stained specimens and 3 specimens mounted for SEM): Body extremely elongate, 9,536-11,002 (3) long, 815-1,060 (3) in maximum width, 9-13 $\times$ longer than wide (Figs. 1-3), penetrating atrial wall and lacing through myocardium (Fig. 4); anterior end tapering more gradually than posterior end; posterolateral protuberance extending 74-172 (3) laterad from body margin, 172 (2) wide at base, 883-1,041 (4) or $9 \%$ (2) of body length from posterior end of body (Figs. 1, 3, 5). Tegument extremely rugose (Fig. 8), with spines; tegumental spines 3 (10) long, 1 (10) wide (Figs. $2,6,7)$; tegumental spine rows consisting of 258-350 (3) rows per side or 516-700 (3) total rows, ending $2,455-4,075$ (3) or $26-36 \%$ of body length from posterior end; rows each measuring 15-27 (3) long, with number of spines per row increasing from anterior end of body mediad, decreasing posteriorly, comprising 6-7
(3) spines anteriorly (Fig. 2), comprising 8-10 (3) spines medially (Fig. 7), and comprising 5-7 (3) spines posteriorly. Ventrolateral nerve cord 15-20 (3) wide, 75-114 (3) from lateral body margin, indistinct posteriorly; commissure perpendicular to midline of body, $144-189$ (2) or $1-2 \%$ of body length from anterior end of body, 35-60 (2) long across width of worm, 15 (2) in diameter (Figs. 1, 2). Dorsolateral nerve cords indistinct. Ventral tegumental sensory papillae posterior to posterolateral protuberance, approximately 50 in number, 5 (5) long, 7 (2) wide at base; sensory cilium associated with papillae not observed.

Mouth 5 (3) in diameter, minute. Oesophagus 8901,105 (3) long or $8-10 \%$ of body length, widening from 5-10 (3) near mouth to 30-35 (3) in medial portion to 50-60 (3) in maximum width posteriorly, having up to 3 curves; oesophageal wall thickening from 3-5 (3) near mouth to 10-12 (3) in posterior portion (Figs. 1, 2). Oesophageal gland enveloping oesophagus, concentrated in area $224-249$ (3) long or $21-25 \%$ of oesophageal length and 149 (3) wide. Caeca containing granular material within lumen; granular material dense, brownish-yellow in live specimens and wholemounts, evenly filling caecal lumen; anterior caeca 114-154 (3) long or $1-2 \%$ of body length, 25-55 (3) wide, with each caecum extending short distance anteriad between oesophagus and ventrolateral nerve cord, not reaching level of oesophageal gland; posterior caeca unequal in length, sinuous, having lateral projections appearing as thorns in lateral view; dextral posterior caecum 4,5414,910 (3) long or $41-52 \%$ of body length and $29-43 \times$ dextral anterior caecum length (dextral posterior caecum longest in 2 of 3 specimens), 25-45 (3) wide, lacking lateral projections posteriorly (Fig. 1), expanding laterally to 40-50 (3) wide posteriorly; sinistral posterior caecum $2,455-4,419$ (3) long or $22-42 \%$ of body length and 19-36 × sinistral anterior caecum length, 25-37 (3) wide, expanding laterally to 30-57 (3) wide posteriorly; intersection of anterior and posterior caeca 940-1,154 (3) or $9-11 \%$ of body length from anterior end. Postcaecal space $3,423-4,860$ (3) long or $36-46 \%$ of body length.

Testis post-caecal, 2,119-3,265 (3) long or 22-31\% of body length, 781-978 (3) wide or $91-96 \%$ of body width, 2.2-4.2 $\times$ longer than wide, lobed, enclosing refractive processes; processes extending dorsoventrally, 5 (2) in diameter. Post-testicular space 1,522-1,694 (3) long or $13-17 \%$ of total body length. Vasa efferentia an interconnecting meshwork of fine ducts entwining throughout testicular tissue, difficult to trace in fixed specimens, contained sperm in all observed specimens, each 12 (1) in diameter, extending primarily dorsoventrally and along ventral surface of testis, uniting in posterior region of testis; vas deferens 522-620 (3) long, 25-35 (3) wide, sinistral, extending posteriad and ventral to testis, not coiling, contained sperm in all observed specimens (Fig. 3). Cirrus-sac 423-457 (3) long, 

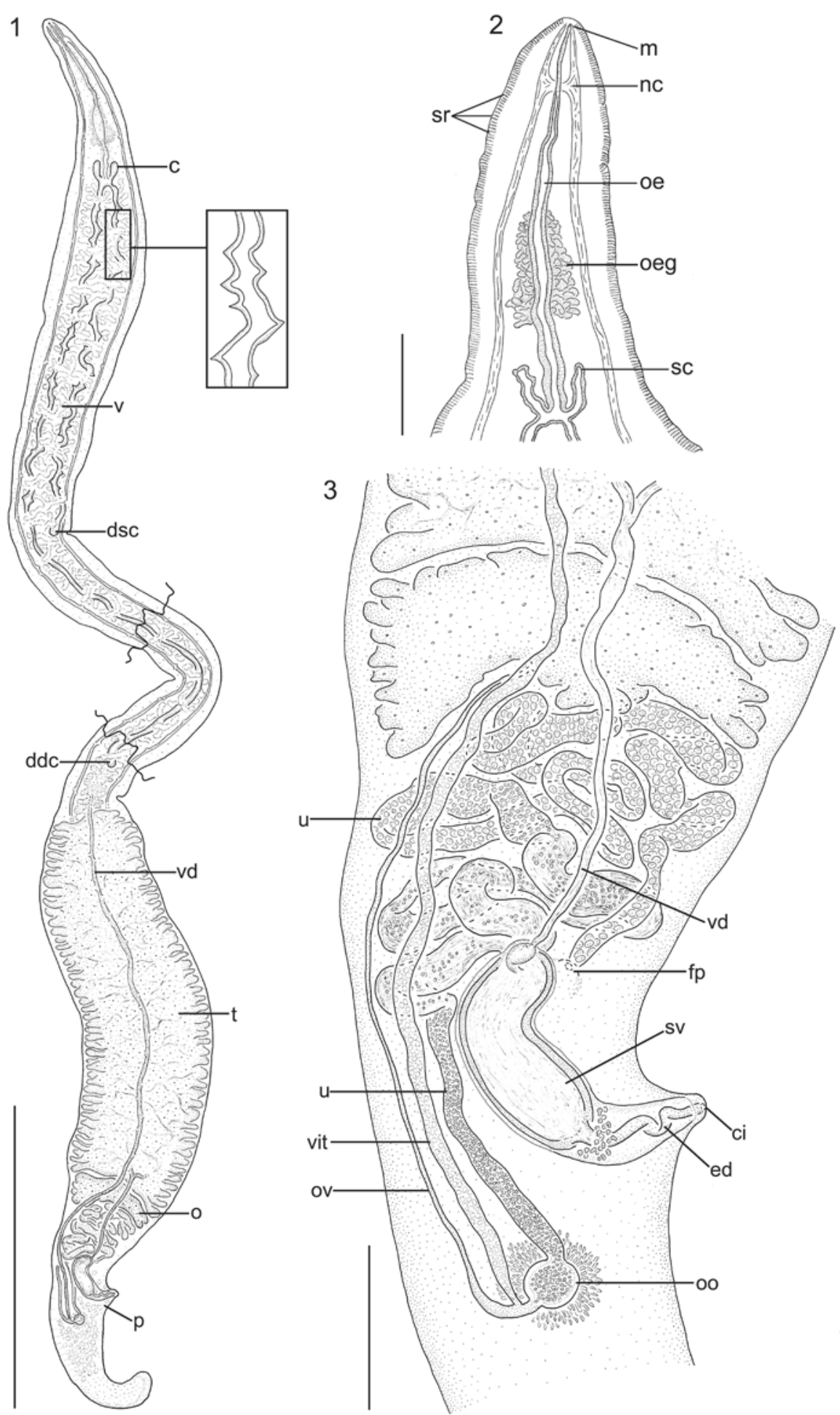

Figs. 1-3. Psettarium anthicum sp. n. (Digenea: Sanguinicolidae) from heart of Rachycentron canadum, adult, ventral view. Fig. 1. Holotype, body showing caeca (c) and inset demonstrating the lateral projections that appear as thorns in lateral view, vitellarium (v), distal end of sinistral posterior caecum (dsc), distal end of dextral posterior caecum (ddc), vitelline duct (vd), testis $(\mathrm{t})$, ovary $(\mathrm{o})$, and posterolateral protuberance $(\mathrm{p})$; jagged lines demarcate the portion of the fluke's body that penetrates the atrial wall and laces through the myocardium. Fig. 2. Composite, anterior end of body showing mouth $(\mathrm{m})$, nerve commissure (nc), lateral tegumental spine rows (sr), oesophagus (oe), oesophageal gland (oeg), sinistral anterior caecum (sc). Fig. 3. Composite, genitalia showing vas deferens (vd), female pore (fp), seminal vesicle (sv), non-everted cirrus (ci) at distal tip of posterolateral protuberance, ejaculatory duct (ed), oötype (oo), uterus (u), vitelline duct (vit), and oviduct (ov). Scale bars: Fig. $1=2$ mm; Fig. $2=500 \mu \mathrm{m}$; Fig. $3=250 \mu \mathrm{m}$. 

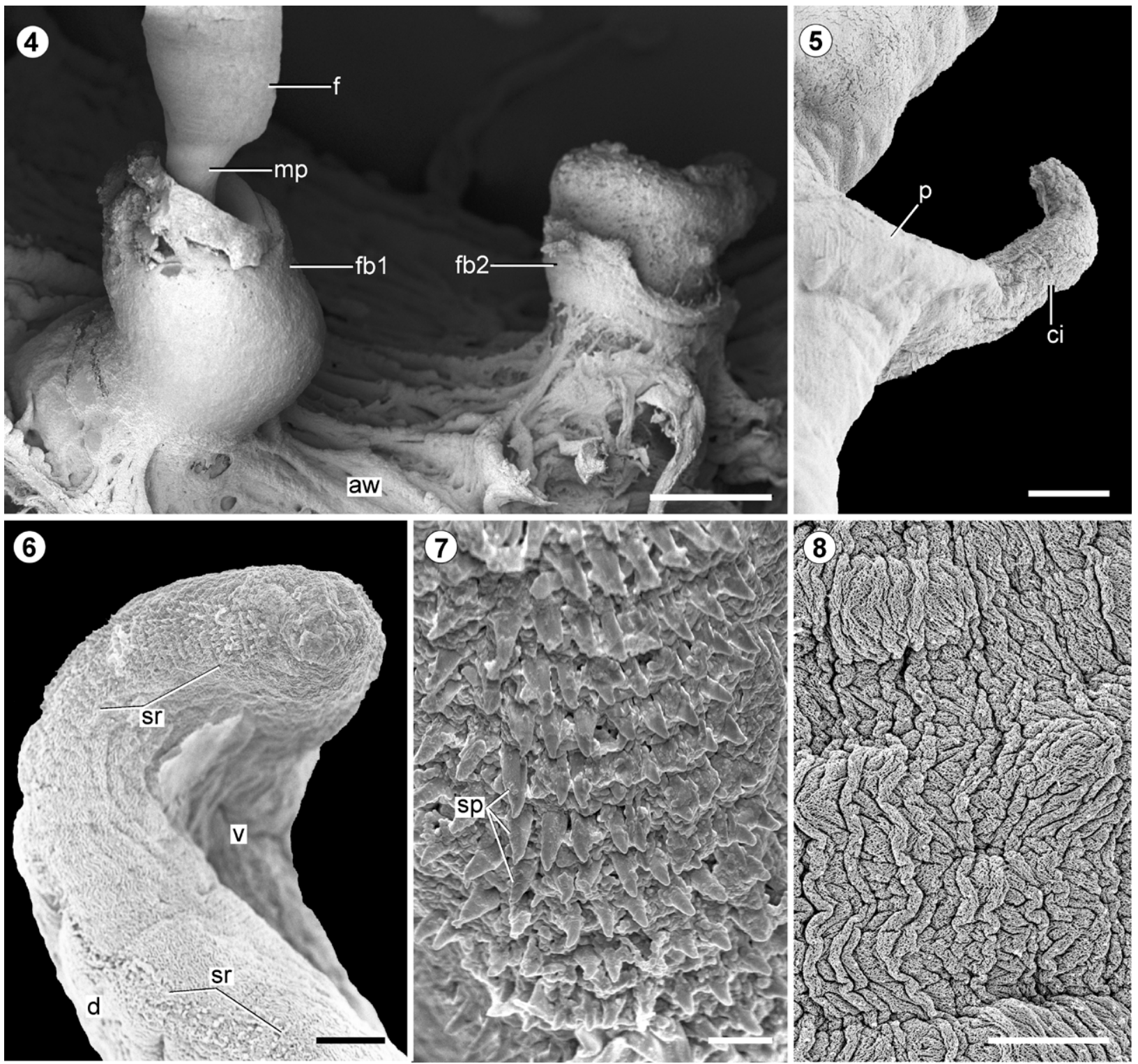

Figs. 4-8. Psettarium anthicum sp. n. (Digenea: Sanguinicolidae) from heart of Rachycentron canadum, adults, scanning electron micrographs. Fig. 4. Atrial wall (aw) of cobia showing posterior region of adult specimen (f) protruding from vase-like collar of fibrotic tissue ( $\mathrm{fb} 1)$ and collar of fibrotic tissue ( $\mathrm{fb} 2)$ surrounding anterior end of the same specimen (this portion of the fluke's body broke free during SEM processing). Note the narrow, constricted middle portion of the fluke (mp) that is evident near the collar's opening; this region corresponds to the posterior jagged line in Fig. 1. Fig. 5. Posterolateral protuberance (p) with everted cirrus (ci), dorsal view. Fig. 6. Anterior region of adult specimen highlighting positions of some lateral tegumental spine rows (sr); ventral surface (v), dorsal surface (d); lateral view. Fig. 7. Higher magnification of lateral tegumental spines (sp) in anterodextral body margin. Fig. 8. Surface of adult specimen showing the rugose tegument that lacks sensory papillae, dorsal view. Scale bars: Fig. $4=100 \mu \mathrm{m}$; Fig. $5=200 \mu \mathrm{m}$; Fig. $6=10 \mu \mathrm{m}$; Fig. $7=2 \mu \mathrm{m}$; Fig. $8=20 \mu \mathrm{m}$.

99-149 (3) wide, having wall 5 (2) thick, enveloping seminal vesicle and cirrus; seminal vesicle 308-363 (3) long, 99-149 (3) wide, having wall 10 (3) thick, postcaecal, post-gonadal, oriented toward sinistral body margin, contained sperm in all observed specimens, having glandular cells surrounding distal end; glandular cells basophilic, lacking obvious collecting ducts and surrounding membrane. Ejaculatory duct 174-178 (2) long or $49-56 \%$ of seminal vesicle length, 17 (2) wide or $13-17 \%$ of seminal vesicle width, having wall approximately 5 thick. Cirrus everting on lateral margin, finger-like, about 400 long (Fig. 5). Post-cirrus space $741-982$ (3) long or 8-9\% of body length (Fig. 1).

Ovary medial, 257-297 (3) long, 583-712 (3) wide or $63-87 \%$ of body width, dorsal to vas deferens, occupying space immediately posterior to testis (Figs. 1, 3). Oviduct 920-994 (3) long, 10-15 (2) wide, extending directly posteriad near body margin, 50-70 (3) in di- 
ameter, 653-845 (3) or 6-8\% of body length from posterior end. Vitellarium consisting of extensive network of narrow interconnecting branching bands, filling space between ventrolateral nerve cord from caecal intersection to anterior margin of ovary, ventral to alimentary tract and testis; secondary collecting ducts indistinct; common collecting duct ventral to gonads, extending sinuously posteriad 940-1,166 (3) from testis before becoming 25-35 (3) wide, joining distal portion of oviduct anterolaterally and forming short common duct before entering oötype (Fig. 3). Mehlis' gland 149-249 (3) long, 124-211 (3) wide. Uterus 24-52 (3) wide near oötype, 50-77 (3) in maximum width, extending anterior to anterior level of cirrus sac before widening and becoming sinuous, extensively convoluted for entire length (Fig. 3). Female pore 12-17 (3) wide, 1,0801,350 (2) or $10-12 \%$ of body length from posterior end (Fig. 3). Uterine eggs spheroid, having thin membrane, lacking thickened shell, 10-15 (3) in diameter or 20$25 \%$ of uterus diameter; released eggs obvious in epithelium of gill filaments and lamellae, 25-35 (5) in diameter, containing a developed (having cilia) or developing (lacking cilia and egg including large, spheroid lipid granules) miracidium, surrounded by mild fibrotic encapsulation. Excretory system not observed.

$\mathrm{T}$ y p e h o s t : Rachycentron canadum (Linnaeus, 1766) (Perciformes: Rachycentridae), cobia.

$\mathrm{S}$ i t e : Adults penetrating atrial wall and laced within myocardium; eggs lodged in epithelium of gill filaments and lamellae.

Prevalence and intensity: 8 of 15 cobia (53\%); 6 had 1-3 flukes each and 2 had 6 each.

T y p e 1 o c a 1 i ty: Northern Gulf of Mexico approximately $50 \mathrm{~km}$ south/southeast of Ocean Springs, Mississippi, USA (Fish Haven-1 site 613-04; 3004’N, 88 $8^{\circ} 37^{\prime} \mathrm{W}$ ).
O the r lo c a li t i e s: Northern Gulf of Mexico off Ship Island, Mississippi $\left(30^{\circ} 15^{\prime} \mathrm{N}, 88^{\circ} 52^{\prime} \mathrm{W}\right)$ and $50 \mathrm{~km}$ south/southeast of Horn Island, Mississippi $\left(29^{\circ} 45^{\prime} \mathrm{N}\right.$, $\left.88^{\circ} 30^{\prime} \mathrm{W}\right)$.

$\mathrm{S}$ p e c i m e n s d e p o s i t e d : United States National Parasite Collection (Beltsville, Maryland, USA), holotype No. 97370 and paratype No. 97372; Institute of Parasitology, Academy of Sciences of the Czech Republic, České Budějovice, paratype D-537.

E t y m o lo g y: The neuter adjectival Greek anthicum refers to the appearance of a plant in a vase, referring to the fluke in the host's fibrotic collar.

Remarks. The new species is most similar to $P$. rachycentri, the other cobia blood fluke, by having posterior caeca with lateral projections appearing as thorns in lateral view, a marginal male pore opening on the tip of a sinistral posterolateral protuberance, a medial ovary with lobes, and a uterus that is extensively convoluted for its entire length. However, P. anthicum is easily distinguished from $P$. rachycentri by having an oötype that is posterior to the male pore; $P$. rachycentri has an oötype that is anterior to the male pore. Further, the position of the testis and the general body shape differs between these species. Psettarium rachycentri has a testis that extends from the caecal bifurcation to the ovary and a body that is relatively more ovoid and tapered equally at both ends. Psettarium anthicum has a post-caecal testis and an extremely elongate body with a broad posterior region that accommodates the testis. The remaining three species of Psettarium, $P$. japonicum, $P$. tropicum, and $P$. sebastodorum, are most easily distinguished from the cobia blood flukes by lacking posterior caeca with lateral projections appearing as thorns in lateral view.

Table 1. Type hosts for accepted species of Psettarium Goto et Ozaki, 1930.*

\begin{tabular}{|l|l|l|l|l|}
\hline Parasite & Type host & Site & Type locality & Reference \\
\hline $\begin{array}{c}\text { Psettarium } \\
\text { japonicum }\end{array}$ & $\begin{array}{l}\text { Takifugu pardalis (Temminck } \\
\text { et Schlegel) (as Spheroides } \\
\text { pardalis), Higan-fugu }\end{array}$ & $\begin{array}{l}\text { intestine (probably within mesen- } \\
\text { teric vessels) }\end{array}$ & $\begin{array}{l}\text { Inland Sea, Japan, } \\
\text { Northwest Pacific } \\
\text { Ocean }\end{array}$ & $\begin{array}{l}\text { Goto and Ozaki } \\
1929\end{array}$ \\
\hline $\begin{array}{c}\text { Psettarium } \\
\text { tropicum }\end{array}$ & $\begin{array}{l}\text { Sphoeroides annulatus (Jenyns) } \\
\text { as Cheilichthys annulatus), } \\
\text { bullseye puffer }\end{array}$ & $\begin{array}{l}\text { coelom washings and once from } \\
\text { intestine, "probably originally in } \\
\text { the blood vessels" }\end{array}$ & $\begin{array}{l}\text { San Francisco, } \\
\text { Ecuador, Southeast } \\
\text { Pacific Ocean }\end{array}$ & Manter 1940 \\
\hline $\begin{array}{c}\text { Psettarium } \\
\text { sebastodorum }\end{array}$ & $\begin{array}{l}\text { Sebastes caurinus Richardson } \\
\text { (as Sebastodes caurinus), } \\
\text { copper rockfish }\end{array}$ & $\begin{array}{l}\text { heart: usually intertrabecular } \\
\text { spaces of the atrium or ventricle; } \\
\text { rarely bulbus arteriosus and ven- } \\
\text { tral aorta }\end{array}$ & $\begin{array}{l}\text { Northeast Pacific } \\
\text { Ocean }\end{array}$ & Holmes 1971a \\
\hline $\begin{array}{c}\text { Psettarium } \\
\text { rachycentri }\end{array}$ & $\begin{array}{l}\text { Rachycentron canadum } \text { (Lin- } \\
\text { naeus), cobia }\end{array}$ & kidney & $\begin{array}{l}\text { Gulf of Mannar, } \\
\text { Indian Ocean }\end{array}$ & $\begin{array}{l}\text { Lebedev and } \\
\text { Parukhin } 1972\end{array}$ \\
\hline $\begin{array}{c}\text { Psettarium } \\
\text { anthicum }\end{array}$ & Rachycentron canadum, cobia & myocardium, atrial wall & $\begin{array}{l}\text { Northern Gulf of } \\
\text { Mexico }\end{array}$ & present study \\
\hline
\end{tabular}

*Except P. sebastodorum, each species has been reported from the type host only; Holmes (1971a, 1971b) and Smith (1997) list other hosts for P. sebastodorum. 
Unlike all other true sanguinicolids, including those that penetrate cardiac muscle (e.g., Ankistromeces mariae Nolan et Cribb, 2004), adults of $P$. anthicum are sedentary. The narrow middle portion of each individual (Figs. 1, 4) threaded through the atrial wall with a surrounding white collar of fibrotic tissue (Fig. 4), and both ends of each individual fluke dangled free within the lumen of the heart. Typically, multiple specimens clustered in a single site and were bound by the same fibrotic response while orienting with the anterior ends directed in the same direction. No specimen detached, wriggled free or crawled while being collected such as, for example, specimens of Cardicola spp. (see Bullard and Overstreet 2004) or Elaphrobates euzeti Bullard et Overstreet, 2003 (see Bullard and Overstreet 2003). The pathological alterations to the myocardium that are associated with infection by $P$. anthicum will be described in a separate study.

Cobia blood flukes may be useful biological tags. Psettarium rachycentri purportedly infects the kidney of cobia in the Indian Ocean only (Lebedev and Parukhin 1972), and we report $P$. anthicum from the heart of cobia in the Gulf of Mexico. We saw neither an adult nor juvenile specimen in the kidney. The life history and migratory habits of cobia are indeterminate, but the cobia is classified as a coastal migratory pelagic species incapable of transoceanic migration. Further, we know of no record of a cobia from the central Atlantic Ocean or from the central or eastern Pacific Ocean (Shaffer and Nakamura 1989). That sister species of Psettarium infect this host species suggests that the cobia in these regions represent distinct, allopatric, stocks.

Diagnostic key to Psettarium spp. (see text for questionable species)

1 Posterior caeca not smooth, uterus convoluted along entire length .......................... 2

- Posterior caeca smooth, uterus not convoluted along entire length ............................. 3

2 Male pore posterior to oötype, testis intercaecal .................................. P. rachycentri

- Male pore anterior to oötype, testis post-caecal .................................... P. anthicum

3 Male pore marginal ............................ 4

- Male pore submarginal ............... P. tropicum

4 Ovary anterior to level of male pore P. japonicum

- Ovary reaching but not anterior to level of male pore ............................. P. sebastodorum

Acknowledgements. We thank Jody Lee Peterson (Gulf Coast Research Laboratory) for skillfully catching most of the cobia we examined from the Northern Gulf of Mexico; Ervin Otvos (Gulf Coast Research Laboratory, The University of Southern Mississippi) for translating the Russian articles; and Kirsten Jensen (The University of Kansas) for generously providing facilities, supplies and expertise for SEM. This study was supported by the National Science Foundation (NSF Award Nos. 0508856, 0529864 and 0608603) and the National Oceanic and Atmospheric Administration, National Sea Grant Program (Award Nos. NA16RG1646 and 114776-GL10013).

\section{REFERENCES}

BULLARD S.A., OVERSTREET R.M. 2002: Potential pathological effects of blood flukes (Digenea: Sanguinicolidae) on pen-reared marine fishes. Proc. Gulf Caribb. Fish. Inst. 53: $10-25$.

BULLARD S.A., OVERSTREET R.M. 2003: Elaphrobates euzeti gen. and sp. n. (Digenea: Sanguinicolidae) from snappers (Lutjanidae) in the Gulf of Mexico. In: C. Combes and J. Jourdane (Eds.), Taxonomie, Écologie et Évolution des Métazoaires Parasites (Livre Hommage à Louis Euzet). Tome 1., PUP Perpignan, pp. 97-113.

BULLARD S.A., OVERSTREET R.M. 2004: Two new species of Cardicola (Digenea: Sanguinicolidae) in drums (Sciaenidae) from Mississippi and Louisiana. J. Parasitol. 90: 128-136.

BULLARD S.A., OVERSTREET R.M., CARLSON J.K. Selachohemecus benzi n. sp. (Digenea: Sanguinicolidae) from the blacktip shark Carcharhinus limbatus (Carcharhinidae) in the northern Gulf of Mexico. Syst. Parasitol. (In press.)

GOTO S., OZAKI Y. 1929: Brief notes on new trematodes II. Jpn. J. Zool. 2: 369-381.

HOLMES J.C. 1971a: Two new sanguinicolid blood flukes (Digenea) from scorpaenid rockfishes (Perciformes) of the Pacific Coast of North America. J. Parasitol. 57: 209-216.
HOLMES J.C. 1971b: Habitat segregation in sanguinicolid blood flukes (Digenea) of scorpaenid rockfishes (Perciformes) on the Pacific Coast of North America. J. Fish. Res. Board Can. 28: 903-909.

LEBEDEV V.I., MAMAEV Yu.L. 1968: [Two new species of Cardicola Short, 1953 (Trematoda: Sanguinicolidae) from fish in the South China Sea.] In: K.I. Skryabin and Yu.L. Mamaev (Eds.), [Helminths of animals of the Pacific Ocean.] Izdat. "Nauka", Moscow, pp. 72-75. (In Russian.)

LEBEDEV V.I., PARUKHIN A.M. 1972: [New sanguinicolids (Trematoda) of fish from the Gulf of Mannar (coast of India).] Biol. Nauki (Mosc.) 4: 7-14. (In Russian.)

LINTON E. 1910: Helminth fauna of the Dry Tortugas. II. Trematodes. Carnegie Inst. Wash. Pub. No. 133: 11-98.

MANTER H.W. 1940: Digenetic trematodes of fishes from the Galapagos Islands and the neighboring Pacific. Rep. Allan Hancock Pac. Exped. 2(14): 329-497.

MANTER H.W. 1947: The digenetic trematodes of marine fishes of Tortugas, Florida. Am. Midl. Nat. 38: 257-416.

PARUKHIN A.M. 1976: New trematode species from fish in the southern Atlantic. Biol. Morya (Vladivost.) 2: 28-30. (In Russian.)

SHAFFER R.V., NAKAMURA E.L. 1989: Synopsis of biological data on the Cobia Rachycentron canadum (Pisces: 
Rachycentridae). NOAA Tech. Rep. NMFS 82, FAO Fisheries Synopsis 153. US Dep. Commerce, $21 \mathrm{pp}$.

SHORT R.B. 1952: A new species of blood fluke from marine fish (Trematoda: Aporocotylidae). (Abstract) J. Parasitol. 38 (4, section 2): 36 .

SHORT R.B. 1953: A new blood fluke, Cardicola laruei n. g., n. sp. (Aporocotylidae) from marine fishes. J. Parasitol. 39: 304-309.

SHORT R.B. 1954: A new blood fluke, Selachohemecus olsoni, n. g., n. sp. (Aporocotylidae) from the sharp-nosed shark, Scoliodon terra-novae. Proc. Helminthol. Soc. Wash. 21: 78-82.

SMITH J.W. 1997: The blood flukes (Digenea: Sanguinicolidae and Spirorchidae) of cold-blooded vertebrates: Part 2. Appendix I: Comprehensive parasite-host list; Appendix II: Comprehensive host-parasite list. Helminthol. Abstr. 66: 329-344.

SMITH J.W. 2002: Family Sanguinicolidae von Graff, 1907. In: D.I. Gibson, A. Jones and R.A. Bray (Eds.), Keys to the Trematoda, Vol. 1. CAB International and The Natural History Museum, London, pp. 433-452.

Accepted 29 January 2006 